\title{
The Effect of Temperature on Recombinant Human Granulocyte Colony Stimulating Factor Production by Pichia pastoris Expression System
}

\author{
Research Center for \\ Biotechnology - LIPI, \\ Indonesian Institute of \\ Sciences, Jalan Raya Bogor \\ Km. 46, Cibinong Science \\ Center, Cibinong 16911, Jawa \\ Barat, Indonesia
}

Submitted: 02-04-2018

Revised: $14-05-2018$

Accepted: 12-06-2018

${ }^{*}$ Corresponding author Yuliawati

Email:

yuliawati.goli@gmail.com

\author{
Yuliawati ${ }^{*}$, Asrul Muhamad Fuad
}

\begin{abstract}
Granulocyte colony stimulating factor (G-CSF) is a haematopoetic growth factor that functions as specific stimulator of the survival, proliferation, and differentiation of precursor cells of the neutrophilic granulocyte cell lineage as well as an activator of mature neutrophil function. The main objective of this work is to compare the effect of different temperature on the production of extracellular recombinant G-CSF in Pichia pastoris. Cells were cultured for $72 \mathrm{~h}$ in baffled shake-flasks at $20^{\circ} \mathrm{C}, 25^{\circ} \mathrm{C}$, and $30^{\circ} \mathrm{C}$ in two different medium; buffered glycerol/methanol-complex medium (BMGY/BMMY) and buffered minimal glycerol/methanol $(\mathrm{BMGH} / \mathrm{BMMH})$ after methanol induction every $12 \mathrm{~h}$. Expressed recombinant hG-CSF in the methylotrophic yeast $P$. pastoris was analyzed with SDS-PAGE. The $23 \mathrm{kDa}$ protein was secreted into the culture supernatant when induced with methanol. Production of recombinant G-CSF protein in $P$. pastoris at $30^{\circ} \mathrm{C}$ at $48 \mathrm{~h}$ incubation after methanol induction every $12 \mathrm{~h}$ is the highest in both complex and minimum medium.
\end{abstract}

Key words: granulocyte colony stimulating factor, complex and minimal medium, temperature, Pichia pastoris

\section{INTRODUCTION}

Granulocyte colony-stimulating factor (G-CSF) also known as colony-stimulating factor 3 (CSF 3) is a colony-stimulating factor hormone. G-CSF is a glycoprotein, growth factor and cytokine produced by a number of different tissues to stimulate the bone marrow to produce granulocytes and stem cells. G-CSF then stimulates the bone marrow to release them into the blood. G-CSF also stimulates the survival, proliferation, differentiation, and function of neutrophil precursors and mature neutrophils. The recombinant human G-CSF synthetized in an Eschericbia coli expression system is called filgrastim (Neupogen). Another form of recombinant human G-CSF called lenograstim is synthesized in Chinese Hamster Ovary cells (CHO cells). G-CSF is produced by endothelium, macrophages, and a number of other immune cells. This natural human glycoprotein exists in two forms, a 174- and 180-amino-acid-long protein of molecular weight 18671.65 dalton and 19600 dalton. The more abundant and more active 174-amino acid form has been used in the development of pharmaceutical products by recombinant DNA (rDNA) technology (Hongbao et al, 2011).

Human granulocyte-colony stimulating factor (hG-CSF) cDNA was expressed in the methylotrophic yeast Pichia pastoris under the control of the alcohol oxydase (AOX1) promoter [Bahrami et al (2007), Bahrami et al (2008)]. Bahrami et al. (2007) was using pPIC9 vector secretion constructed as an expression vector for hG-CSF. Higher levels of hG-CSF was obtained using a P. pastoris Mut+ (methanol utilization fast) phenotype. They also investigated the effects of environmental factors such as temperature and $\mathrm{pH}$ on the $P$. pastoris cell growth and hG-CSF production during fermentation. This study using pPICZ $\alpha A$ vector as an expression vector for $\mathrm{G}-$ CSF. The host cell using P. pastoris SMD1168H.

Cereghino and Cregg (2000) state that $P$. pastoris have been developed as a highly popular expression system for the production of variety of therapeutic proteins. P. pastoris used preferred over eukaryotic expression systems because of its efficiency, simplicity and affordability. This host can typically be grown 
to high cell density and is a potent expression system with great capability to secrete recombinant proteins into the medium (Cereghino et al. 2002). One of the most important features of yeast expression systems is their ability to perform eukaryotic posttranslational protein modifications, such as $\mathrm{N}$ and O-glycosylation, disulfide bond formation, and oligomerization. The majority of therapeutic proteins display one or more posttranslational modifications (PTMs), and these PTMs are often essential for the functionality of these proteins (Corchero et al. 2012)

Recombinant protein in this study using $P$. pastoris as host cell which has been integrated with gcsf gene. This gene was inserted with the c-myc tag and six histidine tag $(6 \times \mathrm{His})$ at Cterminal. It was inserted into pPICZ $\alpha \mathrm{A}$ vector (Invitrogen). For extracellular secretion of recombinant protein, some commercial expression vectors contain a sequence encoding the secretion an epitope tag for affinity purification or detection of the recombinant protein such as $6 \times$ His, FLAG, HA, and c-myc tags are generally included in frame with the gene of interest (Çelik, and Çalık, 2012).

Most processes with $P$. pastoris are run at a temperature of $30^{\circ} \mathrm{C}$, which is optimum for growth. By decreasing growth temperature from 30 to $20^{\circ} \mathrm{C}$, a 3 -fold increase in specific recombinant protein productivity was obtained in chemostat cultures of $P$. pastoris, which was accompanied by a reduced flux through the TCA-cycle, reduced levels of proteins involved in oxidative stress response and lower cellular levels of molecular chaperones (Çelik, and Çalık, 2012).

Fickers (2014) reviewed that bioprocess parameters such as medium composition, $\mathrm{pH}$, temperature, aeration rate, induction and feeding strategies are of utmost (very) importance since it affects directly the production yield. Those parameters vary according to the genotype of the producing strain and/or the recombinant protein. However, there are some guidelines that allow high productivity yields. The main objective of this work is to compare the effect of different temperature in two kinds medium on the production of extracellular recombinant G-CSF in $P$. pastoris SMD $1168 \mathrm{H}$. This study using $\mathrm{pPICZ} \alpha \mathrm{A}$ vector as an expression vector for $\mathrm{G}$ -
CSF. Expressed recombinant Pichia strain is a strain that has been inserted gene recombinant gcsf-cmyc. The gene is a synthetic gene which is the result of the construction of recombinant genes our previous study.

\section{MATERIAL AND METHODS Yeast strain and Plasmid}

The EasySelect ${ }^{\circledR}$ Pichia expression system was used for genetic engineering experiments. The expression vector pPICZa and host cells of P. pastoris SMD1168H containing the AOX1 promoter, which allows rapid growth on methanol as the carbon source, were used for heterologous protein expression of G-CSF. The recombinant $P$. pastoris strain SMD1168H which has been inserted gene gcsf-cmyc was obtained from our previous study.

\section{Protein expression of $P$. pastoris transformants}

Pichia pastoris recombinant which inserted gcsf-cmyc 21 were cultured to evaluate recombinant protein expression according to manual instructions of Pichia expression kit (Invitrogen). One colony of $P$. pastoris recombinant was cultivated in $2 \mathrm{~mL}$ of YPD medium (with zeocin) and was incubated at $30^{\circ} \mathrm{C}$ and $250 \mathrm{rpm}$ for $24 \mathrm{~h}$. This culture was used for production of G-CSF by using $25 \mathrm{ml}$ of BMGY and BMG medium ( $1 \%$ yeast extract, $2 \%$ peptone, $100 \mathrm{mM}$ potassium phosphate buffer $\mathrm{pH}$ 6.0, 1.34\% YNB, $4 \times 10$ $5 \%$ biotin, $1 \%$ glycerol) and BMGH minimum medium $(100 \mathrm{mM}$ potassium phosphate buffer $\mathrm{pH} 6.0,1.34 \%$ YNB, $4 \times 10-5 \%$ biotin, $1 \%$ glycerol). Cultures were incubated at $30^{\circ} \mathrm{C}$ and $250 \mathrm{rpm}$ for $24 \mathrm{~h}$. The cells were harvested aseptically by centrifugation before they were transferred into two different induction medium, 25mL each; which BMMY (1\% yeast extract, $2 \%$ peptone, $100 \mathrm{mM}$ potassium phosphate buffer $\mathrm{pH} 6.0,1.34 \% \mathrm{YNB}, 4 \times 10-5$ $\%$ biotin, 0.5\% methanol) and BMMH $(100 \mathrm{mM}$ potassium phosphate buffer $\mathrm{pH} 6.0,1.34 \%$ YNB, $4 \times 10-5 \%$ biotin, $0.5 \%$ methanol) with starting $\mathrm{OD} 600=5.0$. Cultures were incubated in $100 \mathrm{~mL}$ Erlenmeyer flask at $20^{\circ} \mathrm{C}, 25^{\circ} \mathrm{C}$, $30^{\circ} \mathrm{C}$ and $250 \mathrm{rpm}$ for 3 days and methanol was added at $0.5 \%(\mathrm{v} / \mathrm{v})$ into the culture every $12 \mathrm{~h}$ to induce expression of the recombinant $\mathrm{G}$ CSF gene. P. pastoris cells culture was collected 
every 24 hours after methanol induction for growth and protein analysis. Twenty five mililiter cultures were harvested by centrifugation $\left(10.000 \mathrm{rpm}, 15 \mathrm{~min}, 4^{\circ} \mathrm{C}\right)$. Cell biomass was stored at $-20^{\circ} \mathrm{C}$ and the cell-free culture medium (supernatant) was stored at $4{ }^{\circ} \mathrm{C}$ for further protein analysis.

\section{Protein assay}

Recombinant protein (extracellular product) was analyzed using SDS-PAGE and BCA methods. The BCA Protein Assay Kit (Pierce, Bonn, Germany) was used according to the manufacturer's instructions using test-tube procedure. BCA's method was used with serum bovine albumin as protein standard. Cultures protein were harvested by centrifugation (10.000rpm, $\left.15 \mathrm{~min}, \quad 4^{\circ} \mathrm{C}\right)$. Proteins were precipitated from cell-free supernatant samples by TCA solution (trichloro acetic acid) (Florens \& Washburn, 2008). Sample results of TCA then resuspended in phosphate buffer at $25 \mu \mathrm{L}$. Its used to BCA assay as much $12.5 \mu \mathrm{L}$ sample for the measurement. Then sample added $8 \times$ $\mathrm{cv}$ BCA working reagent and incubated at 37 for $30 \mathrm{~min}$. Once it is added to $500 \mathrm{uL} \mathrm{ddH} \mathrm{d}_{2} \mathrm{O}$ and read at a wavelength of $562 \mathrm{~nm}$.

\section{RESULT AND DISCUSSION}

A recombinant $P$. pastoris strain which can express protein G-CSF-cmyc was constructed in our previous study. Briefly, the gcsf-cmyc gene bearing pPICZ $\alpha \mathrm{A}$ plasmid was introduced into P. pastoris strain SMD1168H to generated the SMD1168H/G-CSF-cmyc strain. The recombinant G-CSF-cmyc expression was confirmed by SDS PAGE and Western Blot analysis, as analyzed in other part of this research. Appeared on SDS PAGE as a protein of $\sim 23 \mathrm{kDa}$ (which corresponds with a theoretical molecular weight of $23 \mathrm{kDa}$ ).

Cos et al. (2005) and Li et al. (2007) stated that heterologous protein expression under control of pAOX1 allows for the design of defined controlled high cell density cultivation strategies for heterologous protein production, described in two main phases. First phase is to generate biomass utilizing carbon sources that lead to a high substrate-biomass yield, such as glycerol; the cells are grown until glycerol is depleted. The second phase, in the presence of methanol, is for induction of foreign protein expression. Optimization of cultivation processses usually involve intermediate cultivation phase, where both carbon sources are present.

To optimize condition for the expression of G-CSF, Pichia transformant were cultured for $72 \mathrm{~h}$ in baffled shake-flasks at, $20^{\circ} \mathrm{C}, 25^{\circ} \mathrm{C}$, and $30^{\circ} \mathrm{C}$ in two different medium; buffered glycerol/ methanol-complex medium (BMGY/ BMMY) and buffered minimal glycerol/ methanol (BMG/BMM). Every treatment was done in triplicate. Recombinant yeasts grew much faster and reach a higher cell density in the complex medium BMMY (OD 600 of 24.8 to 25.77) and in the minimal medium BMM $\left(\mathrm{OD}_{600}\right.$ of 16.6 to 17.39) (Table I). The highest OD on complex medium obtained in temperature $30^{\circ} \mathrm{C}$, while in minimal medium in temperature $25^{\circ} \mathrm{C}$. The rate of methanol conversion determines the available energy and carbon for maintenance, cell growth, product formation and product transport into the media. Overall productivities for cell mass and HSA (human serum albumin) showed similar dependence on methanol concentration as the specific rates (Kupcsulik \& Sevella, 2004).

The environmental condition, e.g. temperature and fermentation processes have close correlation with the cell growth, the internal secretion pathway machinery, the secretion levels of proteins, and their stability in the medium. Another parameter is media composition. The optimal culture medium depends on many factors, including host metabolism, potential inhibitory products, target protein, ect. (Hou et al., 2012). P. pastoris considrable to to produce heterologous proteins. Production of heterologous proteins consisted of two phase; biomass production phase and recombinant protein production phase. In the first phase, as the sole carbon source glycerol is initially added to medium. During this phase, biomass is accumulated, but the gene expression of heterologous proteins is completely repressed. In the second phase, after the initial depletion of glycerol, there is a transition period in which glycerol is added to the culture at a limiting rate (nutritional stress). In many production heterologous protein with $P$. pastoris as a host cell, complex medium is required for growth and induction of protein expression (Aizemberg et al., 2011). 
Table I. Optical Density (OD600) of Pichia pastoris Culture in BMMY and BMM at 72h.

\begin{tabular}{cccc}
\hline Temperature & Bach & BMGY & BMM \\
\hline \multirow{2}{*}{$\mathbf{2 0}^{\circ} \mathbf{C}$} & 1 & 23.60 & 16.52 \\
& 2 & 25.96 & 17.76 \\
& 3 & 25.40 & 17.74 \\
& mean & 24.99 & 17.34 \\
\multirow{2}{*}{$\mathbf{5}^{\circ} \mathbf{C}$} & 1 & 26.94 & 17.64 \\
& 2 & 24.75 & 17.45 \\
& 3 & 22.77 & 17.07 \\
& mean & 24.820 & 17.39 \\
$\mathbf{3 0} \mathbf{0}^{\circ} \mathbf{C}$ & 1 & 26.52 & 16 \\
& 2 & 26.64 & 17.81 \\
& 3 & 24.16 & 15.975 \\
& mean & 25.773 & 16.6 \\
\hline
\end{tabular}
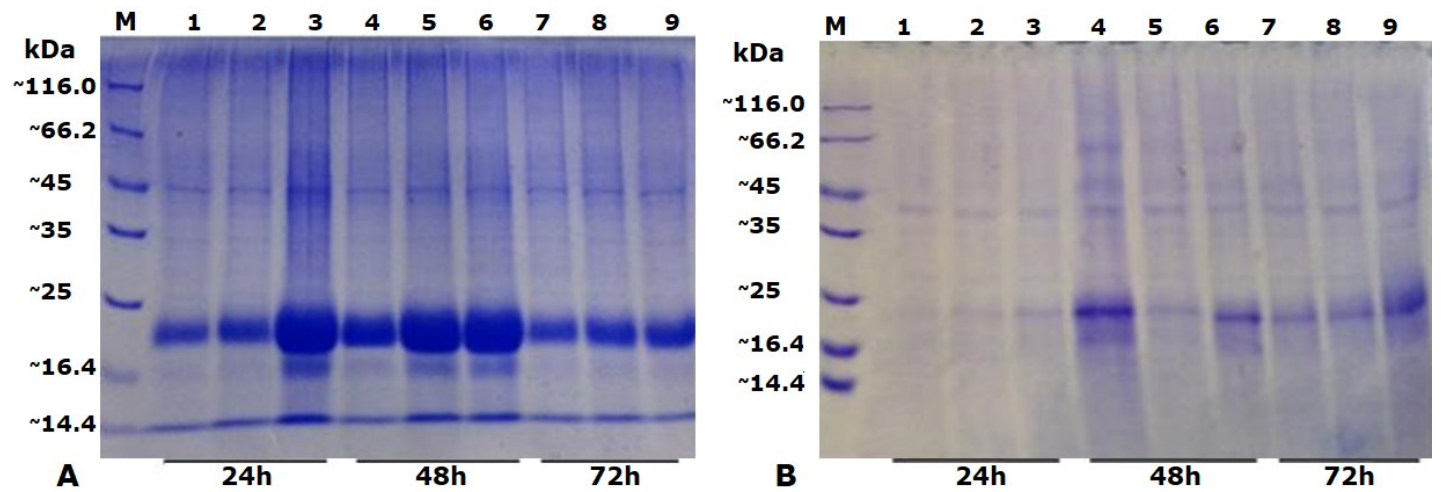

Figure 1. SDS PAGE for G-CSF-cmyc production analysis. (A) Complex medium BMMY and (B) Minimum medium BMM : 1. Marker; 2-4. Protein sample at $24 \mathrm{~h}, \mathrm{t}=20^{\circ} \mathrm{C}, \mathrm{t}=25^{\circ} \mathrm{C}, \mathrm{t}=30^{\circ} \mathrm{C} ; 5-7$. Protein sample at $48 \mathrm{~h}, \mathrm{t}=20^{\circ} \mathrm{C}, \mathrm{t}=25^{\circ} \mathrm{C}$, $\mathrm{t}=30^{\circ} \mathrm{C} ; 8-10$ : Protein sample at $72 \mathrm{~h}, \mathrm{t}=20^{\circ} \mathrm{C}, \mathrm{t}=25^{\circ} \mathrm{C}, \mathrm{t}=30^{\circ} \mathrm{C}$.

Complex medium is used for both growth and induction of protein expression in the field of recombinant protein production from $P$. pastoris. Complex media are excellent for providing the correct chemical environment required for Pichia cell growth, they have some limitations when considering larger-scale and industrial fermentations. The use of minimal media is expected to reduce production costs for a larger scale and industrial scale fermentation.

G-CSF was secreted from Pichia transformant after methanol induction every $12 \mathrm{~h}$ at different temperature $\left(20,25\right.$, and $\left.30^{\circ} \mathrm{C}\right)$ for $72 \mathrm{~h}$. Protein analysis was done after TCA precipitation of culture supernatant on $12 \%$ SDS-PAGE and visualized by commasie blue (Figure 1).
Strategies of combination cultivationlevel (in complex and minimal medium towards temperature) are effective to obtained intact recombinant protein, it was produced by $P$. pastoris with minimum proteolytic degradation. The work described in this section demonstrates the necessity to optimize production/ cultivation process at all levels, not only to achieve maximum growth and protein production, but also to obtain maximal amounts of the desired protein in an intact and bioactive form (Aizemberg et al., 2011). Most of the processes of recombinant protein production by $P$. pastoris are performed at $30^{\circ} \mathrm{C}$ which is the optimal growth temperature (Fickers, 2014) (Figure 1 and Table II) in complex medium the yield of recombinant protein in temperature condition $30^{\circ} \mathrm{C}$ at $48 \mathrm{~h}$ is the highest than other condition 
Table II. Concentration of total recombinant protein G-CSF quantified by BCA method and concentration of target protein was semiquantified with ImageJ software on different media and temperature

\begin{tabular}{lcccc}
\hline \multirow{2}{*}{ Medium } & \multirow{2}{*}{ Time (hour) } & \multicolumn{3}{c}{ Concentration Target Protein $(\boldsymbol{\mu g} / \mathbf{m L})$} \\
\cline { 3 - 5 } & & 20 & 25 & 30 \\
\cline { 3 - 5 } & 24 & 17.14 & 20.94 & 50.66 \\
\multirow{2}{*}{ BMMY } & 48 & 28.31 & 49.81 & 50.47 \\
& 72 & 19.02 & 21.76 & 24.58 \\
\hline \multirow{3}{*}{ BMM } & 24 & 1.37 & 2.02 & 2.27 \\
& 48 & 29.99 & 3.62 & 16.86 \\
& 72 & 6.31 & 6.88 & 23.36 \\
\hline
\end{tabular}

$(50.47 \mathrm{mg} / \mathrm{L})$. Lower cultivation temperature can also influence yields of recombinant protein, possibly due to poor stability of the recombinant protein at higher temperatures, release of more proteases from dead cells, and folding problems at higher temperatures (Aizemberg et al, 2011) as shown in Figure 1 in minimal medium the band of recombinant protein in temperature condition $20^{\circ} \mathrm{C}$ at $48 \mathrm{~h}$ is the highest and the yield protein is $29.99 \mathrm{mg} / \mathrm{L}$.

This study of expression of recombinant protein used complex medium (BMMY) and minimum medium (BMM). On both medium applied three different temperatures i.e. $20^{\circ} \mathrm{C}$, $25^{\circ} \mathrm{C}$, and $30^{\circ} \mathrm{C}$. This is done to determine the best temperature conditions for the expression of recombinant proteins in each media and a preliminary study for the expression of recombinant protein, so it can be applied to larger volume/ fermentor. In heterologous protein production the $\mathrm{pH}$ of growth and induction media play an important role, while optimal $\mathrm{pH}$ range for different heterologous production varied. The $\mathrm{pH}$ of medium in this study adjusted at 6.0. The preference $\mathrm{pH}$ of around 6.0 is all crucial for efficient protein secretion and reducing degradation (Patrick, 2005). The components of BMMY, such as peptone, yeast extracts and steady $\mathrm{pH}$ had prominent effects on the growth and expression of recombinant proteins in P. pastoris (Ling, 2010). Curvers et al., (2001) also study the optimization of $\mathrm{pH}$ and temperature during cultivation were favored to minimize proteolytic activity.
In this study on complex medium (BMMY), the yield of G-CSF-cmyc at $48 \mathrm{~h}$ is the highest concentration in each temperature, and it all decreased at $72 \mathrm{~h}$. In this medium, at temperature $30^{\circ} \mathrm{C}$ concentration on target recombinant protein at $24 \mathrm{~h}$ is closely with the concentration at $48 \mathrm{~h} \quad(50.66 \mathrm{mg} / \mathrm{mL}$ and $50.47 \mathrm{mg} / \mathrm{mL}$ ) and it decreased at $72 \mathrm{~h}$ (Table II). On minimum medium (BMM) the yield of G-CSF-cmyc is very diverse. At temperature $20^{\circ} \mathrm{C}$ on $48 \mathrm{~h}$ occurred the highest concentration and decreased at $72 \mathrm{~h}$. Whereas at temperature $25^{\circ} \mathrm{C}$ and $30^{\circ} \mathrm{C}$ in 24,48 and $72 \mathrm{~h}$ protein recombinant concentration trends are increased, despite at temperature $25^{\circ} \mathrm{C}$ the increase not significant as in temperature $30^{\circ} \mathrm{C}$. To produce recombinant protein as we have observed through the optimization experiment that temperature $30^{\circ} \mathrm{C}$ is the best condition for complex medium. While the best condition to produce recombinant protein for minimum medium in temperature $20^{\circ} \mathrm{C}$. For those medium, the cultivation time are $48 \mathrm{~h} . \mathrm{Li}$ et al. (2007) state that there are several reports on expressing heterologous proteins in P. pastoris at low temperatures. Incubation temperatures of $30,27,25$, and $23^{\circ} \mathrm{C}$ have been examined in attempts to minimize the proteolytic degradation of the recombinant protein in the culture medium, also can reduced rate of protein synthesis which allow more time for the nascent peptide chains to fold properly.

The recombinant G-CSF-cmyc protein after $72 \mathrm{~h}$ of cultivation in complex medium was estimated as 19.02 to $50.47 \mathrm{mg} / \mathrm{L}$, while in 
minimum medium approximately 6.31 to $23.36 \mathrm{mg} / \mathrm{L}$. Chien (2010) reported that gene expression in the protease resistant strain of yeast (SMD1168) the total recombinant G-CSF protein in shaking flask medium was estimated as $15 \mathrm{mg} / \mathrm{L}$. Expressed mGM-CSF in GS115, Jacobs et al. (2010) and Saeedina (2008) also reported have a final yield of $\sim 18 \mathrm{mg} / \mathrm{L}$ and $3.1 \mathrm{mg} / \mathrm{L}$ respectively.

\section{CONCLUSION}

Recombinant $\mathrm{hG}$-CSF produced in the methylotrophic yeast Pichia pastoris analyzed with SDS-PAGE. Protein was secreted into the culture supernatant when induced with methanol, the proteins have a size of $23 \mathrm{kDa}$. Production of recombinant G-CSF protein in $P$. pastoris at $30^{\circ} \mathrm{C}$ at $48 \mathrm{~h}$ incubation after methanol induction every $12 \mathrm{~h}$ is the highest in both complex and minimum medium.

\section{ACKNOWLEDGEMENT}

This research is supported by Indonesian Institute of Sciences (LIPI)'s Competitive Research Program year 2015

\section{REFERENCES}

Aizemberg R., Terrazas WD., Ferreira-Dias S., Valentini SR., Gattás EA. 2011. Optimal conditions for biomass and recombinant glycerol kinase production using the yeast Pichia pastoris. Food Technology and Biotechnology, 49(3), 329.

Bahrami A., Shojaosadati SA., Khalilzadeh R., Farahani EV. 2008. Two-stage glycerol feeding for enhancement of recombinant hG-CSF production in a fed-batch culture of Pichia pastoris. Biotechnology letters, 30(6), 1081-1085.

Bahrami A., Shojaosadati SA., Khalilzadeh R., Saeedinia AR., Vasheghani FE., Mohammadian-Mosaabadi J. 2007. Production of recombinant human granulocyte-colony stimulating factor by Pichia pastoris. Iranian J Bio, 5(3), 162-169.

Çelik E., Çalık P. 2012. Production of recombinant proteins by yeast cells. Biotechnology advances, 30(5), 1108-1118.

Cereghino GPL., Cereghino JL., Ilgen C., Cregg JM. 2002. Production of recombinant proteins in fermenter cultures of the yeast Pichia pastoris. Current opinion in biotechnology, 13(4), 329-332.

Cereghino JL., Cregg, JM. 2000. Heterologous protein expression in the methylotrophic yeast Pichia pastoris. FEMS microbiology reviews, 24(1), 45-66.

Chien SF. 2010. Cloning and expression of bioactive human granulocyte colony stimulating factor in Pichia pastoris. J Chinese Chemical Society, 57(4B), 850-856.

Corchero JL., Gasser B., Resina D., Smith W., Parrilli E., et al., 2013. Unconventional microbial systems for the cost-efficient production of high-quality protein therapeutics. Biotec advances, 31(2), 140-153.

Cos O., Serrano A., Montesinos JL., Ferrer P., Cregg JM., Valero,F. 2005. Combined effect of the methanol utilization (Mut) phenotype and gene dosage on recombinant protein production in Pichia pastoris fed-batch cultures. Journal of biotechnology, 116(4), 321-335.

Curvers S., Brixius P., Klauser T., Thömmes J., Weuster-Botz D., et al., C. 2001. Human Chymotrypsinogen B Production with Pichia pastoris by Integrated Development of Fermentation and Downstream Processing. Part 1. Fermentation. Biotechnology progress, 17(3), 495-502.

Fickers P. 2014. Pichia pastoris: a workhorse for recombinant protein production. Current research in Microbiology and Biotechnology, (2), 354-363.

Florens L., Washburn MP. 2006. Proteomic analysis by multidimensional protein identification technology. In New and emerging proteomic techniques (pp. 159-175). Humana Press.

Hongbao M., Yan Y., Yiwu S., Ma M. 2011. Studies of granulocyte colonystimulating factor (GCSF) in renal stem cells regeneration. Stem Cell. 2011; 2(1):36-65.

Hou J., Tyo KE., Liu Z., Petranovic D., Nielsen J. 2012. Metabolic engineering of recombinant protein secretion by Saccharomyces cerevisiae. FEMS yeast research, 12(5), 491-510.

Jacobs PP., Inan M., Festjens N., Haustraete J., Van Hecke, A., et al., 2010. Fed-batch fermentation of GM-CSF-producing glycoengineered Pichia pastoris under 
controlled specific growth rate. Microbial Cell Factories, 9(1), 93.

Kupcsulik B., Sevella B. 2004. Effect of methanol concentration on the recombinant Pichia pastoris Mut S fermentation. Periodica Polytechnica Chemical Engineering, 48(2), 73-87.

Li P., Anumanthan A., Gao XG., Ilangovan K., Suzara VV., Düzgüneş N., Renugopalakrishnan V. 2007. Expression of recombinant proteins in Pichia pastoris. Applied biochemistry and biotechnology, 142(2), 105-124.

Ling LY., Ithoi I., Fong MY. 2010. Optimization for high-level expression in Pichia pastoris and purification of truncated and full length recombinant SAG2 of Toxoplasma gondii for diagnostic use. Southeast Asian Journal of Tropical Medicine and Public Health, 41(3), 507-513.

Macauley-Patrick S., Fazenda, ML., McNeil B., Harvey LM. 2005. Heterologous protein production using the Pichia pastoris expression system. Yeast, 22(4), 249-270. Saeedinia A., Shamsara M., Bahrami, A., Zeinoddini, M., Naseeri-Khalili, M. A., et al. 2008. Heterologous expression of human granulocyte-colony stimulating factor in Pichia pastoris. Biotechnology, 7(3), 569-573. 